This item was submitted to Loughborough's Research Repository by the author.

Items in Figshare are protected by copyright, with all rights reserved, unless otherwise indicated.

The role of IS capabilities in delivering sustainable improvements to competitive positioning

PLEASE CITE THE PUBLISHED VERSION

http://dx.doi.org/10.1016/j.jsis.2009.05.002

PUBLISHER

(c) Elsevier

VERSION

AM (Accepted Manuscript)

LICENCE

CC BY-NC-ND 4.0

REPOSITORY RECORD

Doherty, Neil, and Mark J. Terry. 2019. "The Role of IS Capabilities in Delivering Sustainable Improvements to Competitive Positioning". figshare. https://hdl.handle.net/2134/8333. 
This item was submitted to Loughborough's Institutional Repository (https://dspace.lboro.ac.uk/) by the author and is made available under the following Creative Commons Licence conditions.

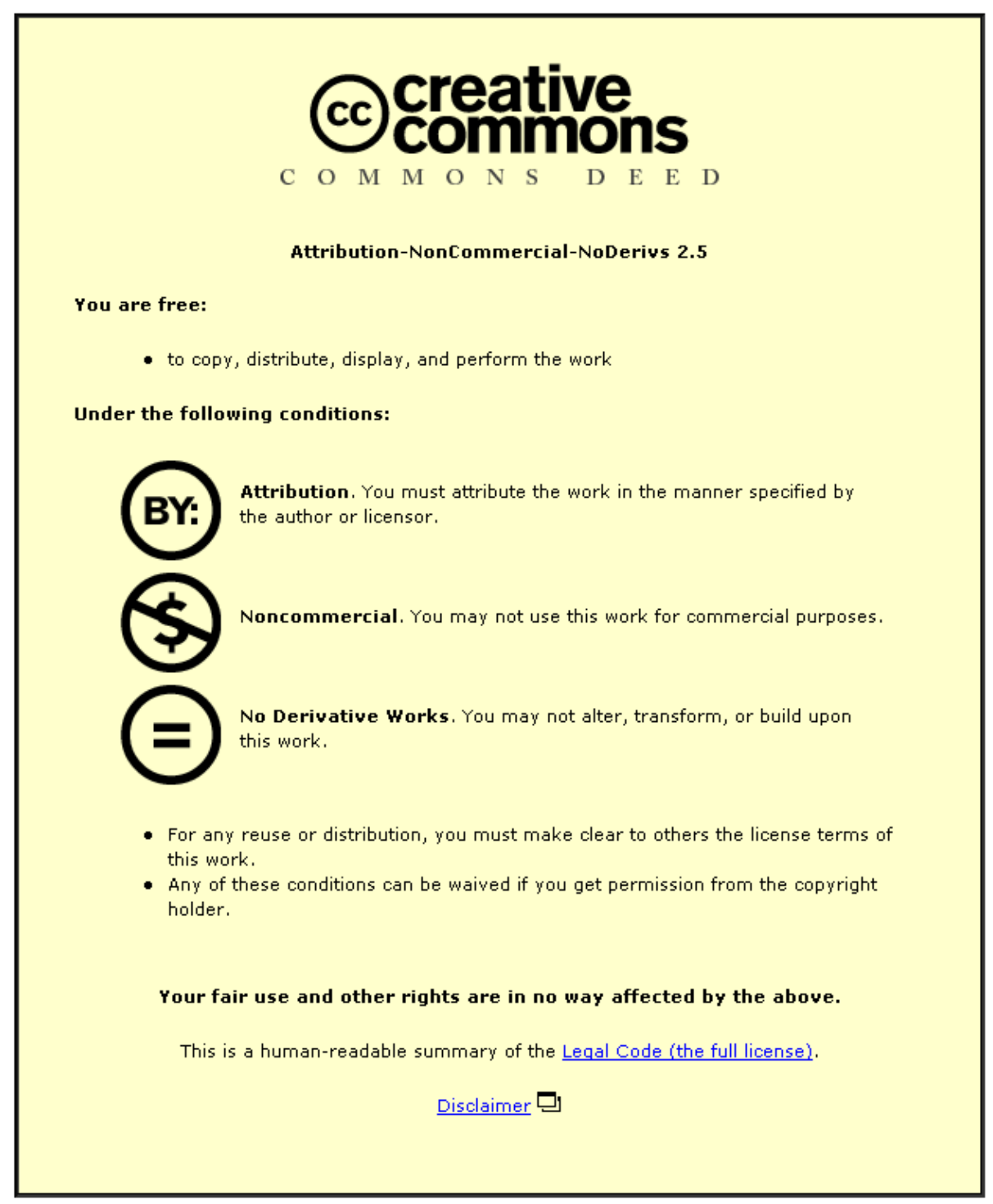

For the full text of this licence, please go to: http://creativecommons.org/licenses/by-nc-nd/2.5/ 


\section{The role of IS capabilities in delivering sustainable improvements to Competitive Positioning}

Neil F. Doherty \& Mark J. Terry

The Business School, Loughborough University, Loughborough, Leicestershire LE11 3TU, UK.

Mailing Address:

Professor Neil F. Doherty

The Business School,

Loughborough University,

Loughborough, LE11 3TU,

United Kingdom.

Telephone: 01509223328

Email: n.f.doherty@ Iboro.ac.uk

Fax:

01509223960 


\begin{abstract}
It has long been argued that organizations have struggled to achieve business benefits, and in particular sustainable competitive advantage, from their IT investments. In this paper we draw upon resource-based theory to explore how the effective deployment of IS capabilities might deliver sustainable improvements to an organization's competitive positioning. In so doing, this research makes a significant departure from the enterprise-level orientation of prior studies, by focusing upon the role of IS capabilities in leveraging sustainable improvements to competitive positioning from individual IS initiatives. Based upon the responses to a quantitative and qualitative survey of practicing managers, it has been shown that an organization's ability to leverage and sustain improvements in its competitive positioning, from IS initiatives, are directly dependent upon its ability to effectively apply an appropriate portfolio of IS capabilities. Moreover, it has been shown that sustainable improvements in competitive positioning are most likely in circumstances in which the successful outcome of an IS initiative is dependent upon 'outside-in' and 'spanning' capabilities, which are both lacking in transparency and difficult to replicate.
\end{abstract}

Key Words: Resource-based View; improved competitive positioning; sustainability; IS capabilities; pluralistic research approaches.

\title{
Introduction
}

Over the past thirty years a great deal of academic effort has been devoted to better understanding how the deployment of IT might support improvements to an organization's operational performance. [Brynjolfsson \& Hitt; 1996 Hitt et al, 2002]. Within this broad domain, a significant number of researchers have been particularly interested in exploring the extent to which the innovative application of IT might have the potential to deliver an outright competitive advantage to their adopters [Mata et al, 1995; Powell \& Dent-Micallef, 1997; Dehning \& Stratopoulos, 2003]. Much of the early work in this field [Ives \& Learmonth, 1984; Porter \& Millar, 1986] adopted a 'competitive forces' perspective, in which competitive advantage is attained when IT is used innovatively to re-write the rules of competition by significantly lowering costs or facilitating differentiation. However, it wasn't long before serious questions were being asked about the sustainability of these strategic information systems [Clemons, 1986; Galliers, 1993].

More recent contributors to this debate have used the 'strategic necessity hypothesis' [Powell \& Dent-Micallef, 1997], to argue that it is unlikely that any individual application of IT will deliver a sustainable competitive advantage. This is so because it is relatively easy for firms to understand, and then copy their competitors' systems, and that failure to do so, will leave them competitively disadvantaged [Melville et al, 2004]. However, even if one accepts that the IT artifact, no matter how innovatively applied, is always susceptible to imitation, it is then possible to draw two very different inferences from this insight. One group of authors would infer from the 'strategic necessity hypothesis', that IT is now such a readily accessible, affordable and homogenous commodity that has limited potential to deliver a sustainable competitive advantage [Carr, 2003; Thatcher \& Pingry, 2007]. By contrast, others would use the resource-based theory of the firm [Wernfelt, 1984; Barney; 1991] to contend that it is possible to gain a strategic advantage if the adoption of information systems is supported 
through the deployment of an appropriate portfolio of complementary resources and capabilities [Wade \& Hulland, 2004]. From these contrasting views, a very lively debate has erupted, within the information systems community, as to whether IT can provide a differential advantage to individual firms [Bhatt \& Grover, 2005], or whether because of its ubiquity, 'IT doesn't matter' [Carr, 2003].

Against this backdrop, the broad aim of this paper is to draw upon resource-based theory, to explore whether it is possible to identify a portfolio of IS-related resources / capabilities that are necessary to facilitate the delivery of sustainable improvements in competitive positioning from the application of business IT. However, in so doing, we make a significant departure from previous studies by using individual IS initiatives as the unit of analysis, and explore the competitive impacts of IT at the process level. To this end, the remainder of the paper proceeds as follows. The next section presents a critical review of the literature, from which the study's specific objectives are derived. We then develop a conceptual framework, before presenting a review of the research methods that were applied to collect data to test the model. The framework then provides the basis for a mixed, quantitative and qualitative analysis, which is presented in the fifth section. We conclude by summarizing the findings and limitations of our study, and by proposing an agenda for future research.

\section{IT-enabled Competitive Positioning: a Critical Review}

The purpose of this section is to provide an overview of the resource-based theory of the firm, before critically reviewing its use in prior studies of the role of IT in delivering sustained improved competitive poisoning. In so doing, gaps in the literature are identified and the objectives of the study explicitly presented.

\section{The Resource-based View [RBV]}

For an organization to realize a competitive advantage, it must satisfy a number of conditions: it must be doing something appreciably better than its competitors, this difference must be valued by its customers, but it must not be readily replicated by its competitors [Day, 1984; Porter, 1985]. Whilst it has been recognized that any competitive advantage is to be valued, it is also recognized that it is likely to be eroded over time, as competitors take steps to imitate the winning formula. Consequently, the holy grail of strategic management is to find sources of sustainable sources of competitive advantage [Porter, 1985], which Barney [1991] defines as ones that: 'continue to exist after efforts to duplicate that advantage have ceased'. In recent years the resource-based view of the firm has attracted many adherents, as it provides a coherent explanation of how any competitive advantage might be sustained.

The origins of the RBV lie in the work of authors, such as Penrose [1959; p.7] who suggested that a firm should be viewed as 'a collection of human and physical resources bound together 
in an administrative framework, the boundaries of which are determined by the area of administrative coordination and authoritative communication'. However, the various writings on the subject didn't really coalesce into a distinctive and coherent theoretical position - the 'resource-based view of the firm' - until the publication of an influential article by Wernerfelt [1984], in which he noted that 'both strategy scholars and managers often failed to recognize that a bundle of assets, rather than a particular product-market combination chosen for its deployment, lies at the heart of their firm's competitive position'. The RBV posits that firms compete on the basis of heterogeneously distributed, 'unique' resources that are valuable, rare, inimitable and non-substitutable - the so called VRIN characteristics [Barney, 1991]. Firms that were once thought of as being homogenous are now seen to be differentiated through their possession of difficult-to-imitate resources, which are responsible for the observed variability in their financial and operational performance [Wernerfelt, 1984]. With respect to the role of IT in competitive positioning, there is a growing recognition, as discussed below, that it is those resources which support the effective application of IT, rather than the technological artifact itself, that are best suited to sustaining a competitive advantage.

\section{Resource Complementarity and IT-enabled Competitive Advantage}

When seeking sources of sustained competitive advantage, it soon became apparent to members of the business and the academic communities, that the speed, power and flexibility of IT might be effectively harnessed [Porter \& Millar, 1986]. Whilst a variety of different theoretical perspectives have been adopted, Melville et al [2004; p. 289] argue convincingly that it is the 'resource-based view of the firm', which is 'inherently suitable for analyzing the complexity of IT and firm performance'. The RBV posits that when searching for IS-based sources of sustainable competitive advantage, organizations must focus less on the role of the technical artifact and more on the potential of the resources/capabilities needed to support and exploit information systems within the firm [Mata et al, 1995; Dehning and Stratopoulos, 2003; Ravichandran \& Lertwongsatien, 2005].

Any researcher wishing to contribute new insights upon the 'under-examined' topic of how 'IT assets affect firm performance' [Ravichandran \& Lertwongsatien, 2005, p. 238], using a resource-based approach, faces the significant problem of which resources and capabilities should be included in the study, as 'so few have been operationalized and examined' [Bhatt \& Grover, 2005 p 258]. There have been several prior attempts to develop lists of IS/IT-oriented resources, capabilities and assets [Bharadwaj, 2000; Peppard and Ward, 2004; Ravichandran \& Lertwongsatien, 2005; Bhatt \& Grover, 2005], but because these frameworks are failing to converge, there is a need for theoretical-based, multi-dimensional measures of 'IT capability', to be established [Santhanam \& Hartono,2003]. In response to this call, and based upon a thorough review of the extant literature, Wade and Hulland [2004] have recently established a comprehensive and coherent framework of eight distinct IS resources, divided into the 
following three broad classes: Inside-out, Outside-in and Spanning. A further problem to face the aspiring RBV researcher, is what terminology should be used as the exact definitions of key concepts such as resources and capabilities have not been agreed upon, and therefore remain ambiguous and controversial [Priem and Butler, 2001]. Whereas the terms 'resource' and 'capability' have often been used interchangeably, some researchers [Amit and Schoemaker, 1993; Makadok, 2001] now make clear distinctions between them. If we apply Makadok's [2001] terminology to the IS domain, then resources are the physical IT assets, such as software, applications and infrastructure, whilst capabilities are the complementary, intangible assets, such as leadership, relationships and culture, needed to leverage value from the physical IS resources.

\section{Critique of Literature and Research Objectives}

Prior resource-based studies of the impacts of IT have typically attempted to assess the economic or competitive impacts of complementary resources, at the enterprise level [see table 1; column 3]. Whilst such studies have delivered many important new insights, there is growing concern that the adoption of aggregate-level of analysis, might lead to very misleading conclusions [Barua et al, 1995; Ray et al. 2004]. Indeed, Piccoli \& Ives [2005; p. 749] have recently called for more studies of the competitive effects of IT that use 'individual strategic initiatives' as the unit of analysis, but to date, this call has not been heeded. Another significant gap in the literature relates to empirical evaluations of the competitive impact of IS capabilities. Most prior resource-based studies have tended to assess the effects of complementary IS / IT resources on firm performance over a fixed three year period [see table 1; columns $7 \& 8$ ], rather than attempting to determine the absolute duration of any improvements in competitive positioning. Moreover, prior studies have not attempted to model the heterogeneity of the contributing IS resources [see table 1; column 5], to determine the extent to which they are perceived to be both transparent and replicable. Consequently, there is much scope for initiating new studies, which adopt alternative, and more flexible, measures of resource heterogeneity and advantage sustainability, and which explicitly focus on IS initiatives, rather than the firm. In addition to attempting to explicitly fill these important gaps in the literature, it was envisaged that this study would make further contributions to the extant literature by empirically assessing the relevance and legitimacy of the Wade \& Hulland [2004] taxonomy of complementary IS resources. 
Table 1: A review of prior RBV studies that examine the impact of IT resources / capabilities upon competitive positioning

\begin{tabular}{|c|c|c|c|c|c|c|c|}
\hline Authors & Date & $\begin{array}{l}\text { Unit of } \\
\text { Analysis }\end{array}$ & $\begin{array}{c}\text { Independent } \\
\text { Variable }\end{array}$ & $\begin{array}{l}\text { Resource } \\
\text { heterogeneity } \\
\text { assessed? }\end{array}$ & $\begin{array}{l}\text { Dependent } \\
\text { Variable[s] }\end{array}$ & $\begin{array}{l}\text { Competitive } \\
\text { advantage } \\
\text { assessed? }\end{array}$ & $\begin{array}{l}\text { Absolute } \\
\text { duration of } \\
\text { advantage I } \\
\text { assessed? }\end{array}$ \\
\hline $\begin{array}{l}\text { Powell \& Dent- } \\
\text { Micallef }\end{array}$ & 1997 & The firm & $\begin{array}{l}\text { Human, } \\
\text { business \& } \\
\text { technology } \\
\text { resources }\end{array}$ & No & $\begin{array}{l}\text { IT \& overall } \\
\text { company } \\
\text { performance }\end{array}$ & $\begin{array}{l}\text { Yes - comparison with } \\
\text { competitors over a } \\
\text { three year period. }\end{array}$ & No \\
\hline Bharadwaj & 2000 & The firm & IT Resources & No & $\begin{array}{l}\text { Various measures } \\
\text { of cost } \\
\text { performance and } \\
\text { profitability }\end{array}$ & $\begin{array}{l}\text { Yes - IT leaders versus } \\
\text { control group }\end{array}$ & No \\
\hline $\begin{array}{l}\text { Santhanam \& } \\
\text { Hartono }\end{array}$ & 2003 & The firm & IT capabilities & No & $\begin{array}{l}\text { Various cost and } \\
\text { profit ratios }\end{array}$ & $\begin{array}{l}\text { Yes - comparison with } \\
\text { competitors over two } \\
\text { three year periods. }\end{array}$ & No \\
\hline $\begin{array}{l}\text { Ravichandran \& } \\
\text { Lertwongsatien }\end{array}$ & 2005 & The firm & $\begin{array}{l}\text { IS capabilities \& } \\
\text { competencies }\end{array}$ & No & $\begin{array}{l}\text { Profitability, } \\
\text { productivity, new } \\
\text { product launches }\end{array}$ & $\begin{array}{l}\text { Yes - comparison with } \\
\text { competitors over a } \\
\text { three year period. }\end{array}$ & No \\
\hline Bhatt \& Grover & 2005 & The firm & IT capabilities & No & $\begin{array}{l}\text { Sales growth and } \\
\text { financial } \\
\text { performance * }\end{array}$ & $\begin{array}{l}\text { Yes - comparison with } \\
\text { competitors over a } \\
\text { three year period. }\end{array}$ & No \\
\hline Rivard et al & 2006 & The firm & $\begin{array}{l}\text { IT support for } \\
\text { strategy \& firm } \\
\text { assets }\end{array}$ & No & $\begin{array}{l}\text { Revenue, market } \\
\text { share, profit } \\
\text { margin, ROI etc. }\end{array}$ & $\begin{array}{l}\text { Yes - comparison with } \\
\text { competitors over a } \\
\text { three year period. }\end{array}$ & No \\
\hline Lin & 2007 & The firm & IT capabilities & No & $\begin{array}{l}\text { ROE, MVA, EVA, } \\
\text { Tobin's Q, market } \\
\text {-to -book ratio }\end{array}$ & $\begin{array}{l}\text { No - absolute } \\
\text { measures of firm } \\
\text { performance used }\end{array}$ & No \\
\hline $\begin{array}{l}\text { Zhang, Sarker \& } \\
\text { Sarker }\end{array}$ & 2008 & The firm & IT capabilities & No & $\begin{array}{l}\text { International } \\
\text { performance of } \\
\text { export-focused } \\
\text { Chinese SMEs }\end{array}$ & $\begin{array}{l}\text { No - absolute } \\
\text { measures of firm } \\
\text { performance used }\end{array}$ & No \\
\hline
\end{tabular}


Based upon this critique of the literature, we wanted to conduct a piece of exploratory work which used individual strategic IS initiatives ${ }^{1}$ as the unit of analysis, and which addressed the following research objectives:

1. To investigate how the application of individual IS capabilities will leverage improvements in competitive positioning from an IS initiative;

2. To explore how the transparency and replicability of individual capabilities will affect the sustainability of any improved competitive positioning;

3. To explore whether the extent to which the competitive positioning of individual processes is affected by the application of IS capabilities;

4. To determine how the transparency and replicability of IS capabilities will affect the sustainability of any improvement, at the process level;

It was envisaged that in testing these objectives, many significant new insights, with respect to the nature, development and relative importance of IS capabilities, might be derived.

\section{Research Framework}

The research framework for this study is comprised four key constructs, which are explicitly measured through the study, and a further two which help to ground the study, but are not measured [see figure 1]. We posit that an organization's ability to leverage an improved competitive positioning from the introduction of an 'IS initiative' will be dependent upon the deployment of an appropriate portfolio of IS capabilities [objectives \#1 \& \#3]. Moreover, we argue that the sustainability of any improvement in competitive positioning (ICP) will be dependent upon the extent to which the contributing capabilities are both non-transparent and non-replicable [objectives \#2 \& \#4]. The form and function of each of these constructs is briefly described in the following discussion.

\section{Information Systems Capabilities}

As noted earlier, a growing number of divergent taxonomies of IS-related capabilities and resources have already been derived [Mata et al. 1995; Powell and Dent-Micallef 1997; Bharadwaj 2000]. For the purposes of this study, we have chosen to adopt Wade and Hulland's [2004], as it is probably one of the more coherent and comprehensive taxonomies, and it explicitly addresses outwardly facing IS capabilities, in addition to the more commonly considered internally focused ones. However, based upon Makadok's [2001] distinction between resources and capabilities, we have termed these 'IS capabilities' [see Appendix A], as all eight are skills, competences and abilities, upon which the value of the physical IT resource can be leveraged.

1 An 'IS initiative' was defined as either as a completely new IS implementation, or a major revision to an existing system, which was explicitly instituted to improve competitive positioning. 


\section{Sustained Improved Competitive Positioning [SICP]}

As Ray et al [2004] note, prior studies of the competitive impacts of IS investments have typically utilized 'highly aggregated dependent variables'; for example, return on sales, market share or new customers. However, it is generally agreed in the literature, that it is difficult to detect the impacts of IS usage, and in particular competitive benefits, in any organizational-level measures of performance [Brynjolfsson, 1993; Cavaye \& Cragg; 1993]. Against this backdrop, many researchers have suggested that the impacts of specific IS implementations might be more meaningfully measured at the process, rather than the firm, level [e.g. Ray et al, 2004; Melville et al, 2004]. As no previous research to date has proposed, validated and applied a generic set of business processes with which to measure the competitive implications of IS, we constructed our own taxonomy of business processes, based upon an extensive review of the literature [e.g: APQC, 2004; Flower, 1998; Pandya et al, 1997]. The resultant framework of eleven generic business processes is presented in Appendix B. In addition to making an important departure from the established literature, by measuring the competitive impacts at the process level, this study also sought to be innovative by focusing on the degree of ICP, rather than focusing solely on situations in which an outright competitive advantage had been realized. For this reason the framework had been designed to model the extent to which the competitive positioning of each of the eleven processes had been improved through the introduction of a specific IS initiative. In terms of the sustainability of any improvement in competitive positioning, we define it simply as: the duration, in years, for which any improvement in competitive positioning can be sustained. 


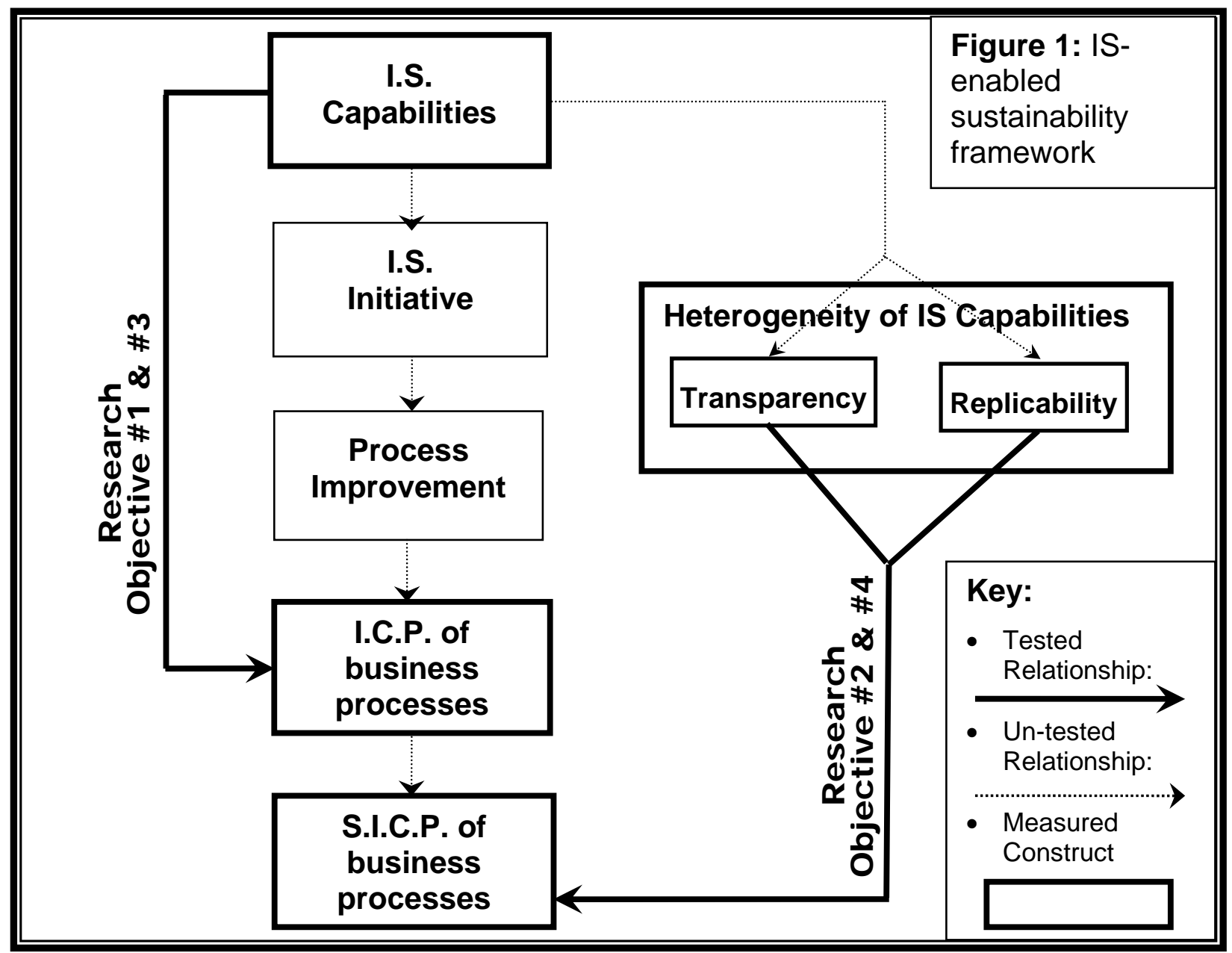

\section{The Heterogeneity of IS Capabilities}

Grant [1991] argues that a firm's ability to sustain a competitive advantage depends upon the speed with which firms can imitate their strategy. Moreover, imitation requires that a competitor overcome two problems. First is the information problem: what is the competitive advantage of the successful rival, and how is it being achieved [transparency]? Second is the strategy duplication problem: can the would-be competitor amass the resources and capabilities required to replicate the successful strategy of the rival [replicability]? Thus, if an organization wishes to imitate the strategy of a rival, it must first identify the capabilities, which underline the rival's competitive advantage and then it must be able to acquire them [Grant 1991]. Consequently, for the purpose of this research, the ability of an IS capability to confer SICP was measured in terms its transparency and replicability.

\section{Research Methods}

There are growing numbers of researchers who choose to combine both quantitative and qualitative approaches in a single study, to build a richer and deeper picture of the phenomenon under investigation, increase the validity of findings and to help explain diverging results [Trend 1989]. Against this backdrop, we chose to follow Cavaye's [1996] advice and collect both quantitative and qualitative data, one after the other, from the same site. Moreover, our research 
philosophy can best be described as 'pluralist', as it incorporated both interpretive and positivist elements, as recommended for the study of complex technologies, in organizational contexts [Mingers, 2004] $]^{2}$. The initial questionnaire survey was executed using positivistic principles, but when analyzing the rich database of interview transcripts, we attempted to adopt more of an 'interpretive' style, as our overarching aim was to gain 'knowledge of reality' through the study of social constructions [Klein \& Myers, 1999]. The aim of this section is to firstly review how a questionnaire was designed, validated and executed, before describing the methods employed for the follow-up qualitative study.

\section{Quantitative study - design, validation and targeting}

A detailed questionnaire, based upon the research model described previously, was used to collect the data necessary to explore the research. As the focus of this study was very different from previous questionnaire-based contributions, it was not possible to adapt specific questions and item measures from the existing literature. Consequently, once a draft questionnaire had been created, it was necessary to subject it to a rigorous validation process. The draft questionnaire was validated through a phased pre-testing regime: firstly, with twelve experienced IS researchers and academics; then, after some amendment, it was re-tested with a different set of seven IS academics; and, finally, with ten practicing managers, all of whom were experienced users of information systems. The pre-tests were very useful, as they resulted in a number of significant improvements being made to the structure of the survey and the wording of specific questions. Having refined the questionnaire, a pilot study exercise involving 57 managers was also undertaken. This provided valuable insights into the likely response rate and analytical implications for the full survey. A discussion of the operationalization of the research variables can be found in Appendix C, whilst a copy of the research instrument has been provided in Appendix D.

\section{Quantitative study - sample targeting and characteristics}

As we were primarily seeking insights into the competitive impacts of IT, it was recognized that the most appropriate group of individuals to target would be managers and executives who had been involved in major information systems initiatives. Consequently, a range of practicing managers was explicitly targeted, as it was envisaged that they could provide the required organizational perspective. Moreover, it was decided to target only large, private sector organizations, as it was felt that smaller companies were unlikely to have the specific in-house IS capabilities, under scrutiny, and it was also envisaged that public sector organizations were unlikely to have the required competitive focus to their operations. Given that we sought to recruit participants who would initially complete a highly complex and commercially sensitive survey instrument, and then be prepared to participate in fairly lengthy interviews, we recognized that there was little likelihood of satisfying these objectives, from a completely random sample.

2 A recent example of such a pluralist approach can be found in Newell \& Edelman (2008). 
Consequently, we decided on a 'convenience sampling' approach, which is becoming increasingly common in similar research contexts, such as IS studies [e.g. Napier et al, 2008; Dinev et al, 2008]; resource-based research [Galbreath, 2005; Wu, 2007], and studies in which interviews are sought [Tarafdar \& Gordon, 2007; Mohdzain \& Ward, 2007]. Consequently, a sampling frame of managers, with whom the researchers' host organizations had professional ties, was constructed. In particular, we targeted the managers of undergraduate students, on their placement year, and practicing managers who had graduated from executive development or executive MBA programs. Each manager was asked to fill out the questionnaire themselves, if they were in a position, so to do, or to pass it on to a suitably positioned colleague.

A total of 109 valid responses were received from the 839 questionnaires successfully e-mailed out, representing a response rate of $13 \%$. Whilst this response rate is perhaps a little disappointing, it is not surprising given the commercially sensitive nature of questions relating to an organization's competitive positioning, and the complexity of the research instrument. However, the fact that our sample comprised responses from organizations representing a wide variety of sizes and sectors ${ }^{3}$, provides much reassurance that our sample is likely to represent a wide spectrum of businesses.

\section{Qualitative study - design, validation and targeting}

The broad aim of the second phase of our study was to revisit each of our research propositions, but this time adopting a qualitative lens, to provide richer and deeper insights, and to help explain and interpret the results of our quantitative study. Consequently, having completed the element of the quantitative study and reflected upon its results, a script of interview questions was developed. The script was explicitly designed to complement and enrich the statistical findings by probing specific aspects of our results that required further clarification or interpretation. For example, interviewees would be reminded of their questionnaire responses relating to the specific business processes, which had attracted an improvement in competitive positioning, and then asked to explain the ways in which these improvements could either be directly or indirectly attributed to the adoption of their IS initiative. However, whilst the interview guide was highly structured, to ensure that all interviewees addressed a set of core themes, it is probably more accurate to describe the process as semi-structured, as the interviewers needed latitude to more deeply probe responses, or explore emerging issues. The provisional interview script was pre-tested with fellow academics to ensure its clarity and relevance, and then pilot tested with five of the original respondents who agreed to participate in the qualitative phase.

3 Of the valid respondents, $33 \%$ were employed in organizations having less than 1,000 employees, $42 \%$ were based in organizations with between 1,000 and 10,000 employees and the remaining $25 \%$ in larger organizations with over 10,000 employees. Whilst the responses were also found to have come from a wide variety of industrial sectors, four were particularly well represented; manufacturing [33\% of sample]; banking and finance [18\%], business services [14\%], and wholesale / retail [10\%]. 
In terms of the targeting for the main phase of the qualitative study, this was relatively straightforward as every respondent to the quantitative study had been asked to tick a box if they would be prepared to participate in a follow-up interview. In total 36 respondents volunteered to participate in the interviews, each of which lasted between 45 and 90 minutes [see Appendix $\mathrm{E}$ for background information on each interviewee]. Each interview was tape recorded and then fully transcribed, and a sample of these was returned to the interviewees to ensure that the process was accurate and free from bias. The interview transcripts were then imported in a rich text format to NVIVO, which facilitated the coding, editing annotation and analysis of the transcripts. More specifically, having applied a set of standard codes across all the to the interview transcripts, to ensure that common themes were treated equably, a hierarchical structure was created, by using 'tree nodes' [Gibbs, 2002], to group related themes together. Having coded all of the data, the 'variable-oriented' form of 'cross-case analysis' [Miles \& Huberman, 1994] was applied, to identify richer patterns, with regard to key constructs, and the relationships between them, across cases.

\section{Research Results}

This section presents the research results with respect to each of the research objectives, firstly through a statistical analysis of the survey data, followed by a qualitative analysis of the followup interviews. To develop a rich picture of the relationships between capabilities and improvements in competitive positioning, a variety of different variables - as described in Appendix F - were adopted for use in the statistical analyses, including summated scales, individual item measures, ranges and maximum values ${ }^{4}$. When choosing the statistical tool, with which to conduct the quantitative analysis, the primary selection criteria was that it should be able to cope with different levels of granularity. Consequently, we chose to adopt correlation analysis as it could be used to explore the complex relationships between the application of IS capabilities and process-level improvements in competitive positioning, at the level of the individual capability and process, as well as in their aggregated forms.

\section{The impact of individual IS capabilities upon ICP \& SICP}

The aim of this section is to explore the impact of individual IS capabilities upon improved competitive positioning [objective \#1], and then upon sustained improved competitive positioning [objective \#3]. The findings in table 2 indicate that a statistical association is evident between six of the individual 'capability contributions' and the 'maximum ICP' [column 4], which provides important new evidence that the appropriate application of IS capabilities, during the conduct of systems development projects, can facilitate the delivery of improvements in competitive

4 It should be noted that summated scales could not be created to incorporate the eleven process improvement variables, as there were too many missing values to apply factor analysis in any meaningful or valid manner Consequently, in the cases of improved competitive positioning, and the sustainability of improvements in competitive positioning, measures of maximum value were employed, as surrogates for summated scales. 
positioning. Moreover, although on average the contributions of the 'inside-out' capabilities' tend to be higher [column 3], it is the 'outside-in' and 'spanning' capabilities that are the most influential, in terms of their ability to deliver an improved competitive positioning [column 4].

Table 2: The Competitive Impacts of Individual IS Capabilities upon Business Processes

\begin{tabular}{|c|c|c|c|c|c|}
\hline $\begin{array}{l}\text { Contributing } \\
\text { Capabilities }\end{array}$ & $\begin{array}{c}\text { Capability } \\
\text { Type }\end{array}$ & $\begin{array}{c}\text { Average } \\
\text { capability } \\
\text { Contribution }\end{array}$ & $\begin{array}{c}\text { Maximum ICP } \\
\& \text { capability } \\
\text { contribution }\end{array}$ & $\begin{array}{c}\text { Maximum } \\
\text { SICP \& } \\
\text { capability } \\
\text { transparency }\end{array}$ & $\begin{array}{l}\text { Maximum } \\
\text { SICP \& } \\
\text { capability } \\
\text { replicability }\end{array}$ \\
\hline $\begin{array}{l}\text { IS Development } \\
\text { contribution }\end{array}$ & Inside-out & 2.04 & 0.171 & -0.141 & -0.115 \\
\hline $\begin{array}{l}\text { IS infrastructure } \\
\text { contribution }\end{array}$ & Inside-out & 3.07 & 0.170 & -0.156 & $-0.212^{*}$ \\
\hline $\begin{array}{l}\text { IS technical skills } \\
\text { contribution }\end{array}$ & Inside-out & 2.34 & $0.259 *$ & $-0.219^{*}$ & -0.147 \\
\hline $\begin{array}{l}\text { Cost effective IS } \\
\text { operations }\end{array}$ & Inside-out & 2.07 & $0.277^{*}$ & $-0.245^{\star}$ & $-0.249 * \star$ \\
\hline $\begin{array}{l}\text { IS planning } \\
\text { contribution }\end{array}$ & Spanning & 1.67 & $0.224^{*}$ & -0.297 ** & $-0.251^{\star *}$ \\
\hline $\begin{array}{l}\text { IS business } \\
\text { partnerships }\end{array}$ & Spanning & 1.94 & $0.351^{\star *}$ & $-0.304^{\star *}$ & $-0.310^{\star \star}$ \\
\hline $\begin{array}{l}\text { External } \\
\text { relationships }\end{array}$ & Outside-in & 1.80 & $0.240^{*}$ & -0.167 & -0.173 \\
\hline $\begin{array}{l}\text { Market response } \\
\text { contribution }\end{array}$ & Outside-in & 1.76 & $0.429 * *$ & $-0.275^{\star \star}$ & $-0.311^{\star *}$ \\
\hline
\end{tabular}

** Significant at the 0.01 level *Significant at the 0.05 level

To determine whether the effect of capability transparency and replicability on the sustainability of ICP, is dependent upon the type of capabilities involved, correlation analyses were conducted between the transparency and replicability of individual IS capabilities and the maximum SICP [columns $5 \& 6$ ]. With regard to the contribution of the transparency of capabilities, all are shown to be negatively correlated with the resultant degree of SICP realized: the lower the level of capability transparency, the higher the level of SICP, and vice versa. However, it will be noted that the effects are generally more significant for the transparency of the 'spanning' and 'outsidein' capabilities than they are for the 'inside-out' capabilities. With regard to the effect of contributing capabilities, that are not easy to replicate, a similar pattern can be discerned. Consequently, based upon these observations, it is possible to conclude that the lower the levels of transparency and replicability exhibited by the contributing capabilities, the higher will be the resultant levels of sustained improved positioning realized. Moreover, it is possible to tentatively suggest that the degree of SICP will be greater in cases in which the success of an IS initiative is dependent upon 'outside-in' and 'spanning' capabilities, that are not transparent or easy to replicate, than would be the case for 'inside-out' capabilities. 


\section{The impact of IS capabilities upon ICP and SICP, at the process level}

It was also possible to explore the relationship between the overall contribution of IS capabilities, to a specific IS-initiative, and the resulting level of improvement to the host organization's competitive positioning, at the process level [objective \#2]. An examination of the data in table 3 reveals a pattern between the levels of 'total capability contribution' and the types of business processes being improved [column 3]. More specifically, whilst IS capabilities have the potential to deliver improvements in competitive positioning in many different processes, it is the operating processes, rather than the management / support processes, in which this effect is most marked.

Table 3: The Competitive Impacts of IS Capabilities upon Individual Processes

\begin{tabular}{|c|c|c|c|c|}
\hline Business Processes & $\begin{array}{l}\text { Average } \\
\text { ICP per } \\
\text { process }\end{array}$ & $\begin{array}{l}\text { Process ICP \& } \\
\text { Total capability } \\
\text { contribution }\end{array}$ & $\begin{array}{l}\text { Process SICP \& } \\
\text { Transparency of } \\
\text { Capabilities }\end{array}$ & $\begin{array}{l}\text { Process SICP } \\
\text { \& Replicability } \\
\text { of Capabilities }\end{array}$ \\
\hline $\begin{array}{l}\text { Designing and developing } \\
\text { products or services }\end{array}$ & 2.24 & $0.243^{*}$ & $-0.332^{\star \star}$ & $-0.324^{\star \star}$ \\
\hline $\begin{array}{l}\text { Acquiring \& storing required } \\
\text { inputs }\end{array}$ & 2.97 & $0.405^{\star \star}$ & $-0.351^{\star \star}$ & $-0.326^{\star \star}$ \\
\hline $\begin{array}{l}\text { Transforming inputs into a } \\
\text { product or service }\end{array}$ & 2.47 & $0.435^{\star \star}$ & $-0.468^{\star \star}$ & $-0.438^{\star \star}$ \\
\hline $\begin{array}{l}\text { Marketing and selling products } \\
\text { or services }\end{array}$ & 1.88 & 0.078 & -0.124 & -0.113 \\
\hline $\begin{array}{l}\text { Delivering products or } \\
\text { services }\end{array}$ & 2.08 & $0.327^{\star \star}$ & $-0.365^{\star \star}$ & $-0.344^{\star \star}$ \\
\hline Customer service & 1.83 & $0.316^{\star \star}$ & $-0.272^{\star \star}$ & $-0.298^{\star *}$ \\
\hline $\begin{array}{l}\text { Developing vision and } \\
\text { strategy }\end{array}$ & 1.83 & $0.242^{\star}$ & $-0.243^{*}$ & $-0.224^{*}$ \\
\hline $\begin{array}{l}\text { Developing and managing } \\
\text { human capital }\end{array}$ & 2.42 & 0.260 ** & -0.096 & -0.142 \\
\hline Managing IT and knowledge & 2.16 & 0.186 & $-0.308^{\star \star}$ & $-0.319 \star \star$ \\
\hline Managing financial resources & 2.19 & 0.055 & -0.068 & -0.053 \\
\hline $\begin{array}{l}\text { Managing external } \\
\text { relationships }\end{array}$ & 1.96 & 0.168 & -0.141 & -0.096 \\
\hline
\end{tabular}

** Significant at the 0.01 level * Significant at the 0.05 level

It was also important to test the aggregate impact of the transparency and replicability of IS capabilities, on the resultant degree of SICP for each of the eleven business processes individually [objective \#4]. From the resultant correlation analyses [columns 4 \& 5], it can then be seen that the degree of SICP for most of the eleven business processes is significantly, and negatively, associated with the degree to which the success of the IS initiative is dependent upon capabilities which are perceived to be both replicable and transparent. Moreover, it is also 
possible to suggest that this effect is generally stronger for the operating processes, than it is for the management/support process.

\section{A qualitative analysis of the Competitive Impacts of IS Capabilities}

Together, the results presented in tables 2 and 3 indicate that IS capabilities have an important role to play in initially leveraging an improved competitive position, and then sustaining the improvement, in circumstances in which the capabilities were perceived to lack transparency and replicability. To explore these relationships further and to test the presence of a causal link, as well as the direction of causality, the interviews explicitly explored the determinants of ICP and SICP.

From our analysis of the qualitative data it became clear that the respondents were generally very positive about the role of IS initiatives in leveraging improvements in competitive positioning. For example, one interviewee $[10]^{5}$ very clearly explained how the introduction of a data warehouse had supplied the customer-oriented information necessary to improve the competitive positioning of the sales and marketing process, by allowing 'new products and services to be developed ahead of the competition'. Another respondent [31] commented, with regard an 'Internet-based CRM system':

'we now have an advantage over our competitors based upon our ability to win orders', through the efficiency of our sales process, because our salesmen can now log onto the system from anywhere and identify which enquiries have been won and closed off and also to see which ones need further follow up'.

The vast majority of the interviewees were also able to provide clear examples of how their IS capabilities had been instrumental in the successful introduction of IS initiatives, from which their improved competitive positioning stemmed. For example:

'I would say the capabilities I have mentioned played an important part in the success of the system and it probably would not have succeeded without them. We probably wouldn't have identified the right system nor been able to link it throughout the organization'. [4]

'Without the capabilities I mentioned, such as supplier relationships etc, I could categorically say that we wouldn't have even got close to implementing a system that was effective as the one that we have now'. [17]

5 Background information on all interviewees can be found in Appendix E. 
'The capabilities mentioned were essential in enabling us to gain the advantages we did from the system... you can't simply implement a system and expect it to give you an advantage... I don't think we would have gotten the advantages we did without them'. [23]

In addition to confirming the existence of a causal chain from the presence of IS capabilities through the delivery of IS initiatives, to the ultimate realization of improvements in competitive positioning, the adoption of the qualitative lens also provided important insights into the role of specific IS capabilities. For example, when commenting on the role of their IS-business partnership capability, one respondent [6] commented: 'without the identification of an appropriate system, we wouldn't have been able to get an advantage at all - I'm not sure that our competitors would be able to do this as effectively as us'. Another respondent when commenting on her organization's external relationship management capability noted: 'Because we worked in conjunction with the supplier we have developed new functionality within the software which our competitors could not simply go out and buy... not many of our competitors would be able to work the way we have with our suppliers [12].

There was also a very high degree of consensus amongst interviewees that the leveraging of an improvement in competitive positioning that was sustainable was dependent upon the utilization of capabilities that were neither transparent nor easily replicable. For example, one respondent clearly articulated the nature of the relationship:

.... 'the success of the system was by and large based on the capabilities we have just discussed. There was nothing else that really helped. So the duration of the advantage is largely based on the time it takes competitors to identify and copy these abilities and implement a similar system'. [14]

Another respondent [5] provided the following clear example of this relationship:

'Our work booking system is quite a simple system, but its sustainability is really coming from our ability to identify the need for it, design it, develop it and implement it. For a company to replicate our ability to do all these things would be almost impossible. For starters even if a company did identify the need for it they would not be able to match our investment in innovation and the development or our infrastructure.

When pressed on which was the most important capability, in terms of sustaining an advantage, many respondents highlighted the importance of 'outside-in' and 'spanning' capabilities, in particular, when it came to sustaining an improved competitive position. For example, with respect to 'IS-business partnerships', one respondent commented:

'It would be very hard for our competitors to identify how our IT department worked with the business side of the organization.... The way IT staff work with the business is deep rooted in the company, it is a culture that has built up over a number of year's with no one set way, just 
the way that works best for us'..... 'it's certainly not something our competitors could go out and copy". [19]

In a similar vein, another respondent [5] highlighted the uniqueness and longevity of his organization's 'market responsiveness' capability:

"We have made a significant investment in innovation, and this is not something that our competitors can go out and buy, as this ability has taken thirty years to develop and build into our culture: we constantly strive to the market leader in terms of IT".

Whereas, the importance of the 'inside-out' capabilities was also recognized, particularly with respect to the initial attainment of an improved competitive positioning, it was felt that as they are generally more transparent and more replicable they have a less significant role to play in terms of sustainability. As one respondent noted when reviewing the importance of his organization's 'IS infrastructure' capability: 'I think it would be obvious that in order to implement this kind of system that you would need a fairly competent IS infrastructure so our competitors would know that we have a good IS infrastructure in order to be able to run it, but they could easily hire in consultants to tell them what they needed' [16]. In a similar vein, when commenting on the transparency and replicability of the 'IS skills' capability, another respondent commented: 'employees know what an acceptable standard for IS personnel is, and how it can be attained, so there's no great myths behind it' [28].

Based upon the above quantitative and qualitative analysis, it can be concluded that the realization of a sustainable improvement in competitive positioning [SICP], from an IS initiative, is dependent upon the utilization of IS capabilities, which are difficult for competitors to understand [non-transparent], and then ultimately replicate'.

\section{Discussion: Contribution, Implications and Limitations}

This wide-ranging study makes a number of important contributions to the information management and strategic management literatures. The aim, therefore, of this section of the paper is to clearly identify and critically review the nature of these contributions, before articulating the study's implications, limitations and areas for future research.

As the work of researchers such as Powell \& Dent-Micallef [1997] and Bhatt \& Grover [2005] have provided many important new insights the role of IS capabilities in enhancing organizational performance, they have been extremely influential in the genesis of this study. However, because these effects have been measured at the enterprise level, such studies can be criticized because they have not been able to demonstrate any direct causal linkage between the application of IS capabilities, and the delivery of improvements in competitive positioning [Ray et al, 2004]. Against this back-drop, we chose to follow Barua et al's [1995] and Piccoli \& 
Ives' [2005] advice by using individual strategic initiatives as the unit of analysis to study the competitive impacts of IT. In so doing, this study presents new evidence that it is the effective application of IS capabilities - to the design, implementation and operation of individual IS enhancements - that has the potential to deliver significant improvements to the organization's competitive positioning, as measured at the process level [see figure 1: objectives \#1 \& \#3]. Moreover, as this study has broken new ground by exploring the impacts of IT capabilities at the level of individual IS initiatives, it has been able to provide some important new insights with regard to the areas in which improvements in competitive positioning are most likely to be attained. Broadly, it is has been shown that it is the operational processes that map onto the primary activities of Porter's [1985] 'value chain', in which improvements in competitive positioning are most likely to be realized. One possible explanation for this is that systems applied to operating processes are more bespoke than their counterparts for support processes, and are thus dependent upon a greater number of IS capabilities. For example, the need for a new accounting or human resources system would almost certainly be satisfied through the purchase of an off-the-shelf package, whilst an IS for production planning and control may very well need to be tailored to an organization's particular operational requirements.

Another area in which this study has made a significant departure from the extant literature [see table 1], is by explicitly investigating the extent to which IS capabilities are judged to be transparent and replicable, and the duration of any resultant improvements in competitive positioning [see figure 1: objectives \#2 \& \#4]. In so doing, it has been possible to demonstrate that when it comes to leveraging and sustaining competitive advantage, not all IS capabilities are equal, as important empirical support has been provided for Wade \& Hulland's [2004] hypothesis that 'spanning' and 'outside-in' capabilities are likely to exert the most significant impact. The most likely explanation of this result is that any improvements in competitive positioning are not solely dependent upon the application of IS capabilities, but are also require the 'co-presence' of other 'complementary organizational resources' [Powell \& Dent-Micallef, 1997; Piccoli \& Ives, 2005], such as organizational culture, leadership and / or unique business processes etc.. Indeed, the results of the qualitative element of our study have shown that it is the capabilities that extend beyond the boundaries of the IT department, which tend to be less transparent and easily replicated, as they are based upon complex relationships between a variety of stakeholders.

In their totality, these findings offer significant new support for the argument [Galliers, 2007; Porter, 2001] that it is not the introduction of information technology, per se, from which improvements in competitive positioning are likely to spring: organizations wishing to leverage improvements in competitive positioning, must invest in, and be able to effectively apply, an appropriate portfolio of enterprise-wide capabilities, to ensure that they are better able to conceive, develop, implement and above all use their information technologies [Wade \& Hulland, 
2004]. However, it must also be recognized that such capabilities cannot be conjured up at short notice, but will require careful planning and nurturing over a protracted period [Peppard \& Ward, 2004].

These findings offer a number of important implications for managers within the business community seeking to deliver improvements in competitive positioning from their investments in IT. For example, the results of this study suggest that success will only come through a longterm program of investment in a coherent and integrated portfolio of complementary capabilities, which are both inwardly and outwardly facing. Moreover, they should be aware that many of the capabilities - and in particular the 'spanning' and 'outside-in' capabilities - are likely to be enterprise-wide, extending well beyond the boundaries of the IT function. Such insights are of particular importance at this period of time, when many organizations are still experiencing significant problems in leveraging value and improvements in competitive positioning from their IT investments [Kiel, 1995; Ashurst et al, 2008]. The findings of this study should also be of great interest to the researcher, as it has demonstrated that it is possible to use the individual IS initiative as the locus for resource-based studies of the competitive impacts of IT. In so doing, this study has identified and validated many new variables, which might be usefully incorporated in future research. In particular, the novel conceptualization and operationalization of our process-oriented measures of ' $I C P$ ', and ' $S I C P$ ' - could be applied within future studies of the delivery of value from IT investments.

Research within complex organizational settings will invariably contain a number of inherent limitations, as compromises and trade-offs are always necessary [McGrath, 1982; Scandura \& Williams. For example, prior RBV studies of the impact of IT upon organizational performance (see table 1), have typically sought 'external validity' (the ability to generalize), at the expense of 'internal validity' (the ability to demonstrate causality). By contrast, as this study has explicitly adopted a research strategy which primarily sought to shed light upon the nature of any causal relationships between resource application and organizational performance, some compromises have had to be made with respect to the generalizability of the results. More specifically, we believed that the only way to ensure a reasonable response rate from a highly complex, in-depth and commercially sensitive questionnaire was through the adoption of a 'convenience' sample. However, we believe that by securing a sample that was varied in terms of organizational size and sector we have managed to overcome some of the typical problems associated with 'convenience' sampling. Moreover, by introducing a significant qualitative element to the study, not only have we been able to validate the causal chain linking the deployment of IS capabilities, through the success of an IS initiative, to the degree of ICP leveraged through the IS initiative, but we have also been able to rule out alternative interpretations of the statistical results. Other limitations, of this study, relate to the use of a 'single-informant', and the use of some 'single item' measures in the statistical analyses, are both approaches, that in an ideal world, might 
have been done differently. Consequently, although this study provides many interesting and novel insights, there is now a pressing need for follow-up studies, which employ different methods and target different populations. In particular, we are now keen to undertake some more detailed, longitudinal case studies, to explore this phenomena more closely, and in so doing, we hope to gain a deeper understanding of the specific mechanisms by which IS capabilities deliver sustainable improvements in competitive positioning.

\section{Acknowledgements}

The authors would like to thank Professor Paul Finlay and Dr Gareth Griffiths for their valuable input during the early stages of this project. The authors are also extremely grateful to Professor Claudia Loebbecke and Professor Bob Galliers, as well as the anonymous referees, for the many helpful suggestions made with respect to initial drafts of this paper, which played an important role in shaping this final version.

\section{Author Biographies}

Professor Neil Doherty currently holds the Chair in Information Management in the Business School at Loughborough University. In addition to IT-enabled improvements in competitive positioning, his research interests include the interaction between organisational issues and technical factors in information systems development, understanding the reasons for failures of information systems projects, strategic information systems planning and E-commerce. Neil has had papers published in a range of academic journals, including: European Journal of Information Systems, Journal of Information Technology, Journal of Strategic Information Systems, Information Resources Management Journal, IEEE Transactions in Engineering Management, Journal of Business Research, European Journal of Marketing, Journal of End User Computing, Information Technology \& People, Behaviour \& IT and Information \& Management. Neil is currently an Associate Editor for Information Technology and People and the International Journal of Electronic Business Research.

Dr Mark Terry is currently the General Manager of KSI Technologies [UK] Ltd. Prior to this he was a graduate research student at the Business School, where he studied for, and successfully attained, a PhD, which investigated the role of IS capabilities in leveraging sustainable improvements in competitive positioning. His research interests include strategic IS strategy, resource-based theory and benefits realization management. 


\section{References}

1. Ashurst, C., Doherty, N.F. and Peppard, J., Improving the Impact of IT Development Projects: The Benefits Realization Capability Model, European Journal of Information Systems, 17, 352-370.

2. Amit, R., \& Schoemaker, P.H., [1993] Strategic Assets \& Organizational Rent. Strategic Management Journal 14, 1, 33-46.

3. American Productivity \& Quarterly Center (APQC) [2004] Process Classification Framework. American Productivity \& Quarterly Center, Houston, Texas.

4. Barney, J.B. [1991] Firm Resources \& Sustained Competitive Advantage, Journal of Management, 17, 1, 99-120.

5. Barua, A., Kriebel, C.H. \& Mukhopadhyay, T. [1995] IT \& Business Value: An Analytic \& Empirical Investigation. Information Systems Research, 6, 1, 3-23.

6. Beard, J.W. \& Sumner, M. [2004] Seeking strategic advantage in the post-net era: viewing ERP systems from the resource-based perspective, Journal of Strategic Information Systems 13, 2, 129-150.

7. Bharadwaj, A.S., [2000] A Resource-Based Perspective on Information Technology Capability \& Firm Performance: An Empirical Investigation. MIS Quarterly 24, 1, 169-196.

8. Bhatt, G. D. \& Grover, V., [2005] Types of Information Technology Capabilities \& their Role in Competitive Advantage: an Empirical Study, Journal of Management Information Systems, 22, 2, 253-277.

9. Brynjolfsson, E. [1993] The Productivity Paradox of Information Technology. Communications of the ACM, 36, 12 66-77.

10. Brynjolfsson, E., \& Hitt, L. [1996] Paradox Lost? Firm-Level Evidence on the Returns to Information Systems. Management Science 42, 4, 541-558.

11. Carr, N. G., [2003] IT Doesn't Matter, Harvard Business Review, 81, May, 41-49

12. Cavaye, A.L.M. \& Cragg, P.B. [1993] Strategic information research: a review \& research framework. Journal of Strategic Information Systems, 2, 2, 125-137.

13. Cavaye, A.L.M.. [1996] Case Study Research: A Multi-Faceted Research Approach for IS, Information Systems Journal, 6, 3, 227-242.

14. Clemons EK. [1986] Information systems for sustainable competitive advantage Information \& Management, 11, 131-136.

15. Day, C.S., [1984] Strategic Marketing Planning: The Pursuit of Competitive Advantage, West, St Paul: MN.

16. Dehning, B. \& Stratopoulos, T. [2003] Determinants of sustainable competitive advantage due to IT-Enabled strategy, Journal of Strategic Information Systems 12, 1, 7-28.

17. Dinev, T., Hart, P. \& Mullen, M. R. [2008] Internet privacy concerns and beliefs about government surveillance: an empirical investigation, Journal of Strategic Information Systems, 17, 214-233.

18. Flower, A. [1998], Operations Management \& Systemic Modeling as Frameworks for BPR. International Journal of Operations \& Production Management, 18, 9, 1028-1056.

19. Galbreath, J. [2005], "Which resources matter the most to firm success? An exploratory study of resource-based theory", Technovation, 25, 979 -987.

20. Galliers, R.D., [1993], "IT strategies: beyond competitive advantage", Journal of Strategic Information Systems 2, 4, 283-291.

21. Galliers, R.D., [2007], On confronting some of the common myths of Information Systems strategy discourse, in The Oxford Handbook on ICT [R Mansell, C Avgerou, D Quah \& R Silverstone (eds.)], Oxford University Press,.225-243. 
22. Gibbs, G.R. (2002), Qualitative Data Analysis: Explorations with Nvivo, Open University Press, Buckingham

23. Grant, R.M. [1991] The Resource-Based Theory of Competitive Advantage: Implications for Strategy Formulation, California Management Review, 33, 1, 114-135.

24. Hitt, L., Wu, D. J. \& Zhou, X. [2002], Investment in Enterprise Resource Planning: Business Impact \& Productivity Measures, Journal of Management Information Systems, 19, 1, 71-98.

25. Ives, B. \& Learmonth, G.P., [1984], The information system as a competitive weapon. Communications of the ACM , 27 12, 1193-1201.

26. Kiel, M. [1995], Pulling the plug: software project management \& the problem of project escalation, MIS Quarterly, 19, 4, 421-447.

27. Klein, H.K. \& Myers, M.D. [1999], A set of principles for conducting \& evaluating interpretive field studies in information systems, MIS Quarterly 23, 1, 67-94.

28. Lin, B-W [2007] Information technology capability and value creation: Evidence from the US banking industry, Technology in Society, 29, 1, 93-106.

29. Makadok, R., [2001], Toward a synthesis of the resources-based \& dynamic-capability views of rent creation. Strategic Management Journal 22, 5, 387-401.

30. Mata, F.J., Fuerst, W.L., \& Barney, J.B. [1995], Information Technology \& Sustained Competitive Advantage: A Resource-Based Analysis. MIS Quarterly 19, 4, 487-505.

31. McGrath, J. E. [1982], Dilemmatics: the study of research choices and dilemmas. In J. E. McGrath, J Martin \& R.A. Kulks [Eds.], Judgment calls in research, 69-102, Newbury Park, CA: Sage.

32. Melville, N., Kraemer, K. \& Gurbaxani, V. [2004] Review: IT \& Organisational Performance: An Integrative Model of IT Business Value, MIS Quarterly 28, 2, 283-322.

33. Miles, M.B., Huberman, A.M. (1994), Qualitative Data Analysis, 2nd ed., Sage, Thousand Oaks, CA.

34. Mingers, J., [2004] Realizing information systems: critical realism as an underpinning philosophy for information systems, Information \& Organization, 14, 87-103.

35. Mohdzain, M. B. \& Ward, J. M. [2007] A study of subsidiaries' views of IS strategic planning in multinational organizations", Journal of Strategic Information Systems, 16, 324-352.

36. Napier, N.P., Keil, M. \& Tan, F. B. [2008] IT project managers' construction of successful project management practice, Information Systems Journal [in press].

37. Newell, S. \& Edelman, L. F. [2008]. Developing a dynamic project learning and cross-project learning cabaility: synthesizing two perspectives , Information Systems Journal, 18, 6, 567591.

38. Pandya, K.V., Karlsson, A., Sega, C. \& Carrie, A. [1997] Towards the Manufacturing Enterprise of the Future, International Journal of Operations \& Production Management 17, 5, 502-521.

39. Penrose, E.T., [1959] The Theory of the Growth of the Firm, New York.

40. Peppard, J. \& Ward, J., [2004] Beyond strategic information systems: toward an IS capability. Journal of Strategic Information Systems 13, 2, 167-194.

41. Piccoli, G. \& Ives, B. [2005] IT-Dependent Strategic Initiatives \& Sustained Competitive Advantage: A Review \& Synthesis of the Literature, MIS Quarterly 29, 4, 747-776.

42. Porter, M.E. [1985] Competitive Advantage: Creating \& Sustaining Superior Performance., Free Press, New York.

43. Porter, M.E. \& Millar, V. [1986] How Information gives you a Competitive Advantage, Harvard Business Review, 64, 4, 149-160.

44. Porter, M. E. (2001). Strategy and the Internet, Harvard Business Review, 79(3), 63-78. 
45. Powell, T.C. \& Dent-Micallef, A. [1997] IT as competitive advantage: The role of human, business, \& technology resources, Strategic Management Journal 18, 5, 375-405.

46. Priem, R.L., \& Butler, J.E., Is the Resource-based [2001], 'View' a Useful Perspective for Strategic Management Research? Academy of Management Review 26, 1, 22-40.

47. Ravichandran, T. \& Lertwongsatien, C. [2005], Effect of Information Systems Resources \& Capabilities on Firm Performance: A Resource-based Perspective, Journal of Management Information Systems 21, 4, 237-276

48. Ray, G., Barney, J.B. \& Muhanna, W.A. [2004] Capabilities, Business Processes, \& Competitive Advantage: Choosing the Dependent Variable in Empirical Tests of the Resource-Based View, Strategic Management Journal 25, 1, 23-37.

49. Rivard, S Raymond, L \& Verreault, D [2006], "Resource-based view and competitive strategy: An integrated model of the contribution of information technology to firm performance", Journal of Strategic Information Systems, 15, 1, 29-50.

50. Santhanam, R., \& Hartono, E., [2003], Issues in Linking Information Technology Capability to Firm Performance. MIS Quarterly 27, 1, 125-153.

51. Scandura, T. A. \& Williams, E. A. [2000] Research Methodology in Management: Current practices, trends and implications for future research. Academy of Management Journal, 43, 6, 1248-1264.

52. Tarafdar, M. \& Gordon, S. R. [2007], "Understanding the influence of IS competencies on process innovation: A resource-based view", Journal of Strategic Information Systems, 16, 353-392.

53. Thatcher, M. E. \& Pingry, D. E. [2007], Modeling the IT value paradox, Communications of the $A C M, 50,8,41-45$.

54. Trend, M.G., [1989] On the Reconciliation of Qualitative \& Quantitative Methods in Evaluation Research, Sage Publications: Beverly Hills.

55. Wade, M., \& Hulland, J. [2004] The resource-based view \& information systems research: Review, extension, \& suggestions for further research. MIS Quarterly, 28, 1, 107-142.

56. Wernerfelt, B. [1984], A resource-based view of the firm, Strategic Management Journal, 5, 2 171-180.

57. Wu, L-Y. [2007], "Entrepreneurial resources, dynamic capabilities and start-up performance of Taiwan's high-tech firms", Journal of Business Research, 60, 549-555.

58. Zhang, M., Sarker, S. \& Sarker, S. [2008], "Unpacking the effect of IT capability on the performance of export-focused SMEs: a report from China", Information Systems Journal, $18,4,357-380$. 
Appendix A: The comparative attributes of IS capabilities [After Wade and Hulland, 2004]

\section{Capabilities \\ Definitions}

\section{Outside-In}

External relationship

The organization's ability to effectively manage linkages between the IS function management

Market

responsiveness

\section{Spanning}

\section{IS-business}

partnerships

IS management/

Planning

Inside-out

\section{Infrastructure \\ Provision} and stakeholders outside the firm.

The organization's ability to collect information from external sources, and disseminate it effectively across departments, to ensure that it can respond rapidly and positively to market intelligence.

IS technical skills

The ability of the firm to effectively integrate and align the IS function with other functional areas or departments, within the organization.

The ability to anticipate future conditions and to effectively develop or acquire appropriate hardware, software, personnel and capabilities, to enable an appropriate response to unfolding circumstances. respect to the organization's informatio
effective deployment and operation.

IS development

Cost effective IS

operations

The capacity of an organization to establish an appropriate portfolio of computer and communication technologies, which can effectively accommodate and integrate a variety of specific applications.

The ability of IS staff to acquire, use, and manage contemporary knowledge with respect to the organization's information systems and technologies, to ensure their

The capacity to rapidly deliver and implement effective IS applications that facilitate agile responses to changing market conditions.

The ability to support and manage effective IS operations on an ongoing and costefficient basis.

\section{Appendix B: A Generic Taxonomy of Business Processes}

\section{Operating processes}

\section{Supporting literature}

Design / development of new products or services

Acquisition and storage of inputs required for product or service production.

Transformation of inputs into the product / service APQC 2004; Malone et al. 1999; Pandya et al. 1997. APQC 2004; Malone et al. 1999.

Marketing and selling products or services

APQC 2004; Pandya et al. 1997; Flower 1998.

Delivery products or services [outbound logistics]

APQC 2004; Pandya et al. 1997.

Customer service and account management

APQC 2004; Malone et al. 1999;

APQC 2004; Pandya et al. 1997; Ray et al. 2004.

\section{Management and support processes}

Vision and strategy development

Development and management of human capital

Development and management of IT / knowledge

Management of financial resources

Management of external relationships
APQC 2004; Pandya et al. 1997; Flower 1998.

APQC 2004; Pandya et al. 1997.

APQC 2004; Pandya et al. 1997; Flower 1998;

APQC 2004; Pandya et al. 1997; Flower 1998.

APQC 2004 


\section{Appendix C - Questionnaire Structure \& Variable Operationalization}

The questionnaire was organized into the following five sections:

- Background information: Respondents were asked to provide some background information, primarily in terms of their company's its size and the industrial sector, in which it primarily operated. Moreover, respondents were asked to identify and briefly describe the IS initiative that they had chosen to be the focal point for their assessment of competitive impacts. Although the 'IS initiative' information didn't play any role in the statistical analysis, it was envisaged that the simple act of providing an explicit description would help the respondents to ensure that they were clearly focused upon a specific strategic initiative before they attempted to answer the remaining questions.

- The contribution of IS capabilities: This section of the questionnaire was designed to evaluate the extent to which the host organization's IS capabilities had contributed to the success of the respondent's chosen IS initiative. To this end, respondents were presented with a generic list of eight potential IS capabilities, based upon Wade \& Hulland's [2004] categorization. For each capability [see Appendix A], respondents were asked to estimate the extent to which it had contributed, using a five point Likert scale, running from low contribution, through to a high contribution.

- ICP of business processes: The key purpose of this section of the questionnaire was to determine the extent to which the respondent's chosen IS initiative had engendered an improvement to their organization's competitive positioning, and the extent to which this improvement had been sustained. For each of these eleven processes [see Appendix B], respondents were asked to indicate how their organization compared to its competitors, both before and after the implementation of their information system, using a 7 point Likert scale that ran from very competitively disadvantaged through to very competitively advantaged. For example, if a respondent reported that before the introduction of an IS, a particular process stood at 'level pegging' [Likert $=4$ ] with its competitors, whilst after implementation, the same process was 'very competitively advantaged' [Likert =7], then the process ICP would be 3 .

- SICP of business processes: Having estimated the extent to which the chosen IS initiative had improved the host organization's competitive positioning, with respect to a specific business process, the respondent was asked to estimate how long he or she believed that this ICP had been, or would be, sustainable. To this end, a fairly simple, yet effective, seven point scale was utilized, that started at 'one year', and progressed to 'seven years or over', in one year increments.

- The heterogeneity of IS capabilities: Having captured the extent to which the success of a specific IS initiative was dependent upon a range of IS capabilities, respondents were invited to record the degree to which they perceived each capability to lack transparency and replicability. For this purpose, two five-point Likert scales were created, ranging from not very transparent, through to extremely transparent; and from not easily replicable, through to very easily replicable. 


\section{Appendix D - Improving business process performance through information systems enhancements}

\section{Confidentiality Statement}

The data obtained from this questionnaire will only be used by the XXX Business School for the purpose of academic research, and no information will be attributed to any person or company.

Before starting the questionnaire please take a moment to think of a computer based information system (IS) enhancement [either a modification to an existing IS or the implementation of a new IS] that has helped improve your firms' competitive position [either getting you ahead of competitors, or enabling you to catch up with them]. Could you please relate all your answers to this chosen system which will be referred to as the 'IS enhancement' throughout this survey.

Please name this IS enhancement:

Please briefly explain the function of the IS enhancement:

\section{Section A: Background information}

1 Which of the following best describes the sector in which your organisation primarily operates?

\begin{tabular}{|l|l|l|l|}
\hline O Agriculture & O Banking and finance & O Business services & O Construction \\
\hline O Education & O Energy supply & O Health & O Leisure \\
\hline O Manufacturing & O Public Services & O Transport & O Wholesale / retail \\
\hline O Other: & \multicolumn{3}{|l}{} \\
\hline
\end{tabular}

2. Approximately how many people are employed in your organisation?

\begin{tabular}{|l|l|l|}
\hline O 1 to 99 & O 100 to 249 & O 250 to 499 \\
\hline O 500 to 749 & O 750 to 999 & O 1000 to 2499 \\
\hline O 2500 to 4999 & O 5000 to 9999 & O 10000 or more \\
\hline
\end{tabular}

Section B: Improved business process performance from the IS enhancement

Please indicate which of the following processes where enhanced as a direct result of the IS by clicking on the appropriate shaded process and filling in the dropdown boxes that appear. If you require any further clarification of a specific process please click on the help icon next to it

\begin{tabular}{|l|l|l|}
\hline The process of designing and developing products or services & View & Help \\
\hline
\end{tabular}

3. Please use scale A to indicate how you compared with your competitors with regards to this process before the implementation of the IS enhancement.

4. Please use scale $B$ to indicate how you compared with your competitors with regards to this process after the implementation of the IS enhancement.

\begin{tabular}{|l|cc|c|ccc|c|}
\hline & $\begin{array}{l}\text { very competitively } \\
\text { disadvantaged }\end{array}$ & & $\begin{array}{l}\text { Level } \\
\text { Pegging }\end{array}$ & & $\begin{array}{r}\text { very competitively } \\
\text { advantaged }\end{array}$ \\
\hline Scale A - Before & $\mathrm{O}_{1}$ & $\mathrm{O}_{2}$ & $\mathrm{O}_{3}$ & $\mathrm{O}_{4}$ & $\mathrm{O}_{5}$ & $\mathrm{O}_{6}$ & $\mathrm{O}_{7}$ \\
\hline Scale B - After & $\mathrm{O}_{1}$ & $\mathrm{O}_{2}$ & $\mathrm{O}_{3}$ & $\mathrm{O}_{4}$ & $\mathrm{O}_{5}$ & $\mathrm{O}_{6}$ & $\mathrm{O}_{7}$ \\
\hline
\end{tabular}

5. With regard to this process please indicate the length of time that you have been, or anticipate you will be able to sustain this improved competitive position.

\begin{tabular}{|l|l|l|l|l|l|l|}
\hline 1 year & 2 years & 3 years & 4 years & 5 years & 6 years & 7 years + \\
\hline $\mathrm{O}_{1}$ & $\mathrm{O}_{2}$ & $\mathrm{O}_{3}$ & $\mathrm{O}_{4}$ & $\mathrm{O}_{5}$ & $\mathrm{O}_{6}$ & $\mathrm{O}_{7}$ \\
\hline
\end{tabular}


Please repeat this procedure for each of the following processes:

\begin{tabular}{|l|l|l|}
\hline The process of acquiring and storing inputs required for products or services & View & Help \\
\hline The process of transforming acquired inputs into products or services & View & Help \\
\hline The process of marketing and selling products or services & View & Help \\
\hline The process of delivering products or services & View & Help \\
\hline The process of developing vision and strategy & View & Help \\
\hline The process of managing information technology \& knowledge & View & Help \\
\hline The process of managing financial resources & View & Help \\
\hline The process of managing external relationships & View & Help \\
\hline The process of customer service & View & Help \\
\hline The process of developing human capital & View & Help \\
\hline Other Process & View & Help \\
\hline
\end{tabular}

Section C: Organisational IS capabilities that contributed to the success of the IS enhancement

Please click on the following Organisational IS capabilities that contributed to the successful implementation of your chosen IS enhancement and fill in the drop down box that appears. If an IS capability did not contribute to the success of the IS enhancement, please click 'not applicable'

\begin{tabular}{|l|l|l|}
\hline Your organisations ability to develop and experiment with new technologies, which & View & Help
\end{tabular} enable you to take advantage of emerging technologies and trends.

6. Please indicate the degree to which this IS capability was a contributing factor in the success of the IS enhancement.

\begin{tabular}{|l|l|l|l|l|}
\hline Low & & & & High \\
\hline $\mathrm{O}_{1}$ & $\mathrm{O}_{2}$ & $\mathrm{O}_{3}$ & $\mathrm{O}_{4}$ & $\mathrm{O}_{5}$ \\
\hline
\end{tabular}

7. Please indicate the ease with which your competitors could understand how the IS capability operates and contributes to the success of the IS enhancement.

\begin{tabular}{|l|l|l|l|l|}
\hline Low & & & & High \\
\hline $\mathrm{O}_{1}$ & $\mathrm{O}_{2}$ & $\mathrm{O}_{3}$ & $\mathrm{O}_{4}$ & $\mathrm{O}_{5}$ \\
\hline
\end{tabular}

8 Please indicate the ease with which your competitors could copy this capability.

\begin{tabular}{|l|l|l|l|l|}
\hline Low & & & & High \\
\hline $\mathrm{O}_{1}$ & $\mathrm{O}_{2}$ & $\mathrm{O}_{3}$ & $\mathrm{O}_{4}$ & $\mathrm{O}_{5}$ \\
\hline
\end{tabular}

Please repeat this procedure for each of the following capabilities:

Your organisation's ability to share information throughout the organisation through effective hardware, software and communication platforms

The ability of your IS staff to understand and use the organisation's hardware, software and communication platforms

Your organisations ability to anticipate future changes and growth, to chose platforms

(including hardware, network and software standards) that can accommodate this change and to efficiently manage the resulting technology change and growth.

Your organisations ability to provide efficient / cost-effective IS operations on an ongoing basis. View Help

Your organisations ability to manage linkages between the IS function and stakeholders

outside the firm i.e. the ability to work with suppliers to develop systems for the organisation.

Your organisations ability to undertake strategic change due to changes in market conditions through the rapid development and management of IS projects

Your organisations ability to ensure IS development plans are integrated with organisational functional plans, and is aligned with organisational needs.

Other capability

\begin{tabular}{|l|l|}
\hline View & Help \\
\hline View & Help \\
\hline View & Help \\
\hline & \\
\hline View & Help \\
\hline View & Help \\
\hline View & Help \\
\hline
\end{tabular}

Please attach your business card if you would be happy to participate in a follow-up interview

Thank you for completing the questionnaire 
Appendix F: Profile of Interview Respondents

\begin{tabular}{|c|c|c|c|}
\hline Respondent & Sector & Size & Type of System \\
\hline 1 & Wholesale \& Retail & $2500-4999$ & Electronic Point of Sales System \\
\hline 2 & Manufacturing & $1000-2499$ & Corporate benchmarking tool \\
\hline 3 & Manufacturing & Not Known & Video conferencing system \\
\hline 4 & Banking \& Finance & $5000-9999$ & Database Management Information \\
\hline 5 & Business Services & $1000-2499$ & Work booking \& allocation system \\
\hline 6 & Manufacturing & $250-499$ & 3D CAD system \\
\hline 7 & Other & Over 10000 & $\begin{array}{l}\text { Knowledge based system to store documents in a } \\
\text { 'corporate memory' }\end{array}$ \\
\hline 8 & Banking \& Finance & $2500-4999$ & Treasury management system \\
\hline 9 & Business services & $100-249$ & 3D CAD project \\
\hline 10 & Banking \& Finance & $2500-4999$ & Data Warehouse \\
\hline 11 & Manufacturing & $1-99$ & Electronic Document Management \\
\hline 12 & Business Services & $1000-2499$ & $\mathrm{SAP} R / 3$ \\
\hline 13 & Manufacturing & $2500-4999$ & Logistics Shipping System \\
\hline 14 & Banking \& Finance & $100-249$ & Financial Risk Management System \\
\hline 15 & Business Services & Not Known & Sales Order Processing System \\
\hline 16 & Business Services & Over 10,000 & Knowledge Management System \\
\hline 17 & Not Known & Not Known & Call Centre Management System \\
\hline 18 & Manufacturing & $100-249$ & Paperless Production System \\
\hline 19 & Wholesale \& Retail & $2500-4999$ & SAP implementation \\
\hline 20 & Manufacturing & $1000-2499$ & Data mining tool \\
\hline 21 & Manufacturing & $500-749$ & Viewer Drawing Document \\
\hline 22 & Not Known & Not Known & Data warehouse system \\
\hline 23 & Business Services & $750-999$ & Knowledge Management database \\
\hline 24 & Other & $250-499$ & $\begin{array}{l}\text { Centralised, web based, document storage \& } \\
\text { distribution system }\end{array}$ \\
\hline 25 & Other & $100-249$ & $\begin{array}{l}\text { A customer-facing web based tool, for customer } \\
\text { support }\end{array}$ \\
\hline 26 & Banking \& Finance & $5000-9999$ & Recruitment System \\
\hline 27 & Transport & $250-499$ & Microsoft Navision \\
\hline 28 & Banking \& Finance & Over 10000 & Customer services system \\
\hline 29 & Energy supply & $1000-2499$ & Metering Database \\
\hline 30 & Other & Over 10000 & J D Edwards ERP system \\
\hline 31 & Manufacturing & $100-249$ & Customer Relationship Management \\
\hline 32 & Business Services & Over 10000 & Extension to SAP \\
\hline 33 & Business Services & $100-249$ & Database of stored documents \\
\hline 34 & Education & $5000-9999$ & Timetabling package \\
\hline 35 & Business Services & $2500-4999$ & $\begin{array}{l}\text { Mobile Connect Card: To enable remote PC } \\
\text { working to office based systems. }\end{array}$ \\
\hline 36 & Public Services & $1000-2499$ & New corporate web site \\
\hline
\end{tabular}


Appendix F: Summary and description of variables used in the quantitative analysis

\begin{tabular}{|c|c|}
\hline Variable & Description \\
\hline Process ICP & $\begin{array}{l}\text { Improved competitive positioning for a specific individual process realized } \\
\text { from an IS initiative }\end{array}$ \\
\hline Maximum ICP & $\begin{array}{l}\text { The 'process ICP' for the process with the greatest degree of improved } \\
\text { competitive positioning, for a given IS initiative }\end{array}$ \\
\hline $\begin{array}{l}\text { Capability } \\
\text { contribution }\end{array}$ & $\begin{array}{l}\text { The extent to which a specific capability contributed to the success of a } \\
\text { particular IS initiative }\end{array}$ \\
\hline $\begin{array}{l}\text { Total capability } \\
\text { contribution }\end{array}$ & $\begin{array}{l}\text { Total degree of IS capability contribution to the success of the IS initiative, } \\
\text { calculated by summating all the measures of 'capability contribution'. }\end{array}$ \\
\hline Process SICP & $\begin{array}{l}\text { The sustained improved competitive positioning for each improved business } \\
\text { process, as calculated by multiplying the 'process ICP' by the number of } \\
\text { years it will be sustained. }\end{array}$ \\
\hline Maximum SICP & $\begin{array}{l}\text { The 'process SICP' for the process with the highest degree of sustained } \\
\text { improved competitive positioning, for a given IS initiative. }\end{array}$ \\
\hline $\begin{array}{l}\text { Capability } \\
\text { Transparency }\end{array}$ & $\begin{array}{l}\text { Transparency of a specific capability contributing to the success of the IS } \\
\text { initiative }\end{array}$ \\
\hline $\begin{array}{l}\text { Capability } \\
\text { Replicability }\end{array}$ & $\begin{array}{l}\text { Replicability of a specific capability contributing to the success of the IS } \\
\text { initiative }\end{array}$ \\
\hline $\begin{array}{l}\text { Transparency of } \\
\text { capabilities }\end{array}$ & $\begin{array}{l}\text { Summation of all the measures of 'capability transparency', contributing to } \\
\text { the success of the IS initiative }\end{array}$ \\
\hline $\begin{array}{l}\text { Replicability of } \\
\text { capabilities }\end{array}$ & $\begin{array}{l}\text { Summation of all the measures of 'capability replicability', contributing to the } \\
\text { success of the IS initiative }\end{array}$ \\
\hline
\end{tabular}

